A paper by William Falkowski, "Scabs on Strike: Polish Immigrant Workers and the 1893 Lumbershovers' Strike in the Tonawandas, New York," showed that workers who are scabs one day can become roaring militants the next, pointing to the oftentimes emphemeral nature of working-class consciousness. Polish immigrant workers, recruited from Buffalo's East Side to break the strike of local workers in the nearby dock town of the Tonawandas, staged their own strike in response to a changeover from hourly to weight-rate wages and the suspension of their free beer break. Striking local workers and the Poles then joined in a one-day celebration of their newfound solidarity, supported by local merchants' donations of food, drink, and cigars. When the Poles returned the next day to demand their wages for the previous week of work, they threatened to burn down the docks unless they were promptly paid. A riot ensued and martial law was declared, with the state militia being called in to restore order.

Although striking local workers responded to the Poles' decision to join the strike with a show of friendship, they did not welcome the Poles into the ranks of their union. Confronted by armed force, lacking organization, faced with the reluctance of the Polish immigrant community's middle class to offer more than token support, and given the willingness of other workers to scab, the Poles' strike soon dissipated. So, too, did the strike of the local dockworkers, who were compelled to accept terms that entailed the disbanding of their union. Falkowski concluded that it was ultimately the responsibility of unions to mobilize immigrant support if strikes were to prove successful. All too rarely, even when presented with a golden opportunity as in the case of the scabs' strike in the Tonawandas, did unions prove capable of the task.

In the discussion that followed, commentator Howard Kimeldorf (University of Michigan) spoke to the dangers of taking an overly behavioralist stance in assessing worker protest or the lack thereof. Several members of the audience took Bright to task in this respect for not considering the context of workers' actions (or inactions). For example, Calgary workers may well have joined the armed forces not because they lacked working-class consciousness but, rather, to gain an increase in wages or simply to get out of Calgary.

\title{
French-American Radicals and Labor Activists, 1848-1914: A Projected Biographical Dictionary
}

\section{Michel Cordillot and Hubert Perrier}

Université Paris-Nord

This is an interim report on a project launched under the auspices of the Atelier de Recherches et d'Etudes Nord-Américaines (ARNA) based at the University of Paris-Nord, in collaboration with other institutions in Europe and the U.S., to 
produce a biographical dictionary of French-American radicals and labor activists covering the period 1848-1914. About twenty scholars are already actively involved in the project.

Political migration from France to the United States began with the arrival of Cabet and his followers. From 1848 onward, several hundred Icarians sailed to the New World, hoping to build there an ideal society whose success would trigger a general movement. A few years later, a cohort of Phalansterians headed by Considerant tried to found another colony in La Reunion, Texas. Both attempts eventually failed, but dozens of French socialists settled in the U.S. In the meantime, many other French radicals had reached American shores, following the convulsions of the Second Republic and Napoleon III's coup d'état. Among them were such luminaries of French-American radicalism as Joseph Déjacque, Claude Pelletier, Frédéric Tufferd, and Daniel Debuchy. Others arrived after the U.S. Civil War, including exiled Communards after May 1871.

After 1880 and until World War I, French political emigration to the U.S. gradually dwindled; still, French-speaking socialist and anarchist groups continued to recruit members and sympathizers among the economic immigrants, especially miners.

Throughout the period, there existed numerous organizations bringing together on a linguistic basis radical republicans, revolutionaries, and socialists of diverse schools. During the 1850 s, French-American radicals played a prominent role in the branches of the International Workingmen's Association. After the Civil War, on October 20, 1868, former Icarians set up the Union Républicaine de Langue Française in St. Louis, and local branches were quickly formed where sizeable French colonies existed. In 1871-1873, the tremendous impact of the Paris Commune on the French-American communities led to the formation of fifteen French sections of the First International, whereas only two had existed prior to the insurrection. One should also mention the setting up of a Société des Réfugiés de la Commune and of several Blanquist groups. Still later, there existed a handful of French sections of the Socialist Labor party from its birth in December 1877 through the early 1880 s, as well as isolated French assemblies of the Knights of Labor. Several anarchist and revolutionary-socialist groups remained active until World War I.

So far, the thorough researching of archival deposits and of most French radical newspapers published in the U.S. (such as Le Libertaire, Le Bulletin de l'Union républicaine, and Le Socialiste) has made it possible for us to start gathering information on some 2,800 individuals. For the period $1868-1880-$ the heyday of the French socialist movement in the U.S. - we have on file 1.375 members and sympathizers of the Union Républicaine and of the French sections of the International, including 126 former Communards. We have respectively 400 and 300 individual entries for the Icarians and the Fourierists. To these should eventually be added some 200 radical republicans, 300 anarchists and draftdodgers, and a still unknown number of socialists and syndicalists. 
This dictionary, devised as the continuation of Jean Maitron's monumental Dictionnaire biographique du mouvement ouvrier français, is aimed at reconstructing the political itinerary of those militants who engaged in political activities on two continents and at reaching a better knowledge of the different groups and fractions that existed among French political immigrants. In this respect, the research done for and around our project has already yielded substantial results, including a collection of papers edited jointly by Bernard Cook, Michel Cordillot, and Hubert Perrier, soon to be published in the U.S. under the title Liberty and a Better New World: Essays in the History of French-American Radicals and Labor Activists. The dictionary should also provide insights into the role that some French-American militants-like V. Drury or L. Sanial-played in the history of the U.S. socialist and labor movements.

It is also hoped that the dictionary will shed some light on the widely debated notion of labor republicanism. French radicals carried with them values, symbols, and a language that belonged to a transnational vein of democratic radicalism. These were to a large extent compatible with the preoccupations of many plebeian, working-class, and reform movements in the U.S., and the interaction between French-speaking and other radicals is a promising field of study. At the same time, the question may be raised whether they did not evince some distinctive traits including a strong inclination towards atheism, the tendency to stand for out-andout radicalism, and a proud attachment to France as the alleged Mother of Revolution-which complicated their relations with other segments (both nativeborn and immigrant) of the labor and radical movements.

Our research should, finally, enable us to address some more general questions pertaining to the issue of (im)migration and ethnicity. Recent studies have stressed the necessity to examine such questions within the framework of a transAtlantic perspective. There is certainly much to be gained by adopting such a viewpoint; at this stage of our study, the examination of scores of individual and group trajectories has already cast considerable light on such problems as the interaction between social movements in the Old and New Worlds, mutual influences in the ideological and organizational fields, and the existence of militant networks across the Atlantic.

In short, we regard this dictionary as a step in the process of achieving an indepth knowledge of French-American radicalism - reconsidered as much as possible in the larger context of a U.S. multinational labor movement and of a transAtlantic migration process - so as to explore the complex relationship between national and social identities.

Any offer of help or collaboration and any relevant information will be gratefully welcomed. All correspondence should be sent to ARNA, c/o Prof. Hubert Perrier, UFR Lettres et Sciences de l'Homme, Université Paris-Nord, avenue J. B. Clément, 93430 Villetaneuse, France. 